\title{
Operationele leases en het voorspellen van faillissement
}

\section{Mijntje Lückerath-Rovers}

SAMENVATTING In dit artikel wordt het empirisch onderzoek beschreven naar de bijdrage van de informatie over operationele leaseverplichtingen (in de toelichting op de jaarrekening) bij het voorspellen van faillissement. Uit het onderzoek onder 38 beursondernemingen in financiële problemen (waaronder 21 gevallen van faillissement of surseance) en 62 gezonde beursondernemingen gedurende de periode 2000-2004 blijkt dat ondernemingen in financiële problemen relatief meer operationele leaseverplichtingen hebben dan gezonde ondernemingen, maar dat de nauwkeurigheid van de voorspelmodellen niet significant verbetert. Deze resultaten kunnen bijdragen aan de discussie welke lease accounting-methode superieur is: de huidige methode waarbij operationele leases slechts in de toelichting op de jaarrekening worden vermeld of de methode waarbij zowel financiëleals operationele leases op de balans gekapitaliseerd worden.

1

Dit artikel richt zich op de vraag of de informatie over operationele leaseverplichtingen in de toelichting op de balans en winst- en verliesrekening, een bijdrage kan leveren aan betere voorspellingen van faillissementvoorspelmodellen. Volgens de internationale accounting-standaarden (Financial Accounting Standard 13, "FAS13"; International Accounting Standard 17, "IAS17" en in Nederland, Richtlijn 292

Dr. M. Lückerath-Rovers is universitair docent Financiële Markten en Toezicht aan de Faculteit der Rechtsgeleerdheid van de Erasmus Universiteit Rotterdam. Zij is gepromoveerd op het proefschrift: 'Operating-Lease Disclosure. An empirical investigation.'

Met dank aan de redactie van het MAB voor hun commentaar op een eerdere versie van het artikel.
"RJ292" van de Raad voor de Jaarverslaggeving, de RvJ) worden operationele leases echter niet op de balans verwerkt. Operationele leases worden beschouwd als een vorm van huur, waardoor de leasebetalingen in de winst- en verliesrekening tot uitdrukking komen; wel dienen in de toelichting gegevens te worden verstrekt over de aangegane leaseverplichtingen. Financiële leases worden daarentegen wel op de balans verwerkt; het geleasde actief wordt op de balans opgenomen en hierop wordt afgeschreven en de leaseverplichting, zijnde de contante waarde van de toekomstige leasebetalingen, staat credit op de balans. De leaseverplichting maakt deel uit van het vreemd vermogen. Operationele leases worden dus anders verwerkt dan financiële leases ${ }^{1}$ en dit heeft belangrijke gevolgen voor de financiële ratio's die worden afgeleid uit de cijfers in de balans en winsten verliesrekening. Deze financiële ratio's worden veelal gebruikt als verklarende variabelen in modellen voor faillissementvoorspelling.

Doordat operationele leases niet op de balans worden opgenomen wordt hiermee geen rekening gehouden in deze faillissementvoorspelmodellen. Het is mogelijk met behulp van gegevens die ondernemingen moeten verstrekken in de toelichting, en op basis van een aantal veronderstellingen (zie hiervoor o.a. Lückerath-Rovers, 2007), nieuwe ratio's te berekenen waarbij wel rekening wordt gehouden met de operationele leases. In deze berekeningen worden de ratio's dusdanig aangepast dat operationele leases worden behandeld als financiële leases (de operationele leases worden "gekapitaliseerd") en worden ratio's opgenomen in de modellen die de lease-intensiteit beogen te meten.

Empirisch onderzoek naar het voorspellen van faillissement door middel van financiële ratio's (o.a. Dimitras et al., 1996; Lennox, 1999; Beaver et al., 2005) heeft aangetoond dat het opnemen van vooral rentabiliteit-, solvabiliteit- en cashflow-ratio's als verklarende variabelen in faillissementvoorspelmo- 
dellen leidt tot betere voorspellingen van faillissement. Daarnaast heeft eerder onderzoek aangetoond dat vooral solvabiliteit- en rentabiliteitratio's significant verslechteren als operationele leases op de balans gekapitaliseerd worden (onder andere Imhoff et al., 1991; Imhoff et al., 1997; Beattie et al., 1998; Bennet en Bradbury, 2003; Ely, 1995 en Lückerath-Rovers, 2007). Toch zijn er slechts twee studies waarbij het effect van operationele leases op het voorspellen van faillissement is onderzocht (Elam, 1975; Lawrence en Bear, 1986). Elam (1975) deed dit door middel van het aanpassen van de financiële ratio's die al in het model als verklarende variabele werden gebruikt, Lawrence en Bear (1986) voegden hier nog een aparte leaseratio aan toe. In beide studies is onderzocht of het kapitaliseren van de operationele leaseverplichtingen (op basis van gegevens uit de toelichting op de balans en winst- en verliesrekening) tot betere voorspellingen leidt van een faillissement in de gehanteerde voorspelmodellen; beide studies kwamen tot de conclusie dat dit niet het geval is.

Vanwege een aantal redenen is een hernieuwd onderzoek op zijn plaats. Allereerst is sinds de tachtiger jaren het gebruik van (operationele) leases als financieringsvorm nationaal en internationaal enorm toegenomen (zie o.a. Leaseurope, 2005; LückerathRovers, 2007; SEC, 2005). Ten tweede is de beschikbare informatie over operationele leases in de toelichting op de jaarrekening verbeterd (Lückerath-Rovers, 2004). Ten derde hebben operationele leases een significante invloed op vooral de solvabiliteitratio's (o.a. Imhoff et al., 1991; Beattie et al., 1998; LückerathRovers, 2004) en deze ratio's hebben tevens een belangrijke voorspellende waarde in de faillissementvoorspelmodellen (o.a. Lennox, 1999; Beaver et al., 2005). En ten slotte, is er kritiek op de gebruikte statistische methode en dataverzameling in voorgaande studies en dit vereist een update van de methodologie (o.a. Ohlson, 1980; Collins en Green, 1982). In dit artikel rapporteer ik over een empirisch onderzoek onder Nederlandse beursgenoteerde ondernemingen. Nederlandse data omtrent operationele leases is vergelijkbaar met internationale studies aangezien zowel het gebruik van operationele leases door Nederlandse beursfondsen als de lease accounting-methode vergelijkbaar zijn met andere landen (Lückerath-Rovers, 2007).

Daarnaast is de discussie rondom de verwerking van operationele leases in de jaarrekening, na eerdere studies in 1996 en 2000 (McGregor, 1996; IASB, 2000; Lennard en Nailor, 2000), opnieuw actueel. De Financial Accounting Standards Board (FASB) en de International Accounting Standards Board (IASB) hebben in 2006 een werkgroep geformeerd met als doel in 2008 met een gezamenlijk voorstel te komen om alle leases op de balans te verwerken; zodoende zou het onderscheid tussen operationele en financiële leases verdwijnen (IASB, 2006). Ook het onderzoek van Elam in 1975 vond plaats ten tijde van de discussie rond het wel of niet kapitaliseren van leases, namelijk rond de invoering van FAS 13 (ingevoerd in 1976²) waarbij het onderscheid tussen financiële leases en operationele leases werd ingevoerd. Elam (1975, p. 25) hoopte met zijn studie een bijdrage te leveren aan de discussie welke accounting-methode voor leases superieur is (vanuit het oogpunt van het voorspellen van faillissementen) door te onderzoeken of kapitalisatie de gebruiker van de jaarrekening beter in staat stelt faillissementen te voorspellen.

In dit artikel, 32 jaar na Elam's studie, wordt zijn onderzoeksvraag opnieuw onderzocht. Dit artikel draagt bij aan de kennis omtrent het gebruik van operationele leases en kan zinvolle informatie opleveren voor de werkgroep van IASB en FASB bij de bepaling of alle leases op de balans gekapitaliseerd moeten worden. Het is daarmee onderdeel van de (bredere) vraag of de informatie over operationele leases in de toelichting wel voldoet aan de kwalitatieve criteria van nuttige informatie ${ }^{3}$ in de jaarrekening, zoals gedefinieerd in de verschillende conceptual frameworks van de regelgevers (zie bijvoorbeeld FASB, 1980 of IASB, 2003). Als blijkt dat de gebruikers van de jaarrekening betere voorspellingen maken met alle leases gekapitaliseerd op de balans, kan dit bijdragen aan de discussie welke lease accountingmethode superieur is. De beperking van dit artikel is dat het vanuit het gebruik van faillissementvoorspelmodellen een bijdrage levert aan bovengenoemde discussie. De vraag of operationele leases überhaupt op de balans thuishoren strekt veel verder en behelst ook de vraag: dient een onderneming activa op de balans te verwerken die zij gebruikt maar die zij niet in haar macht heeft?', (Raad voor de Jaarverslaggeving, in een brief van 3 augustus 2002 naar aanleiding van het rapport van de IASB, 2000). Daarnaast is de vraag waarom failliete ondernemingen meer operationele leases zouden hebben dan gezonde ondernemingen, niet onderzocht.

De opzet van dit artikel is als volgt. Allereerst zullen in paragraaf twee de studies van Elam (1975) en Lawrence and Bear (1986) worden beschreven en vergeleken. Paragraaf drie zal vervolgens de opzet van het onderzoek beschrijven, waarna in paragraaf vier de resultaten besproken worden. Paragraaf vijf sluit af. 


\section{Voorgaande studies met operationele leases 2 in het faillissement - voorspelmodel}

De onderzoeksvraag in deze studie is dezelfde als in de studies van Elam (1975) en Lawrence en Bear (1986)): verbeteren de voorspellingen van faillissementvoorspelmodellen als hierin de operationele leases als verklarende variabele worden meegenomen? Met andere woorden: worden betere voorspellingen gerealiseerd als operationele leases gekapitaliseerd zouden worden? De voorgaande studies van Elam (1975) en Lawrence en Bear (1986) zullen daarom als startpunt dienen voor deze studie.

\section{Elam, 1975}

Elam (1975) was de eerste studie waarbij onderzocht werd of het opnemen van de operationele leaseverplichtingen in het model een bijdrage levert aan de nauwkeurigheid van een faillissementvoorspelmodel. Het doel van zijn studie (p. 25) was 'met nieuwe informatie een bijdrage leveren aan de discussie welke lease accounting-methode superieur is' (on- of off-balance). Meer concreet, stelde Elam (p. 25), wilde hij 'een poging doen te bepalen of het kapitaliseren van leases de gebruiker van de jaarrekening beter in staat stelt faillissementen te voorspellen dan de huidige accounting methode' (in die tijd waren alle leases nog off-balance). Elam onderzocht 48 failliete ondernemingen met operationele leases, waarover informatie werd verstrekt in de toelichting, in de periode 1966-1972. Elke failliete onderneming werd gekoppeld (op basis van de sector en omvang) met een niet-failliete onderneming, met als extra voorwaarde dat deze onderneming ook informatie over operationele leases in de toelichting vermeldde. Elam onderzocht 28 financiële ratio's en paste deze ratio's, indien van toepassing, aan voor de operationele leaseverplichtingen. Op basis van de contante waarde van de toekomstige leaseverplichtingen werd een aanpassing gemaakt voor de nettowaarde van de materiële vaste activa, de langetermijnverplichtingen en het totaal vermogen. Dit had gevolgen voor 13 van de 28 financiële ratio's. Elam gebruikte geen aparte leaseratio's (waarbij bijvoorbeeld de omvang van de operationele leaseverplichtingen gerelateerd wordt aan het balanstotaal), omdat het doel van zijn studie was 'het onderzoeken van de effecten van kapitalisatie op al bewezen financiële ratio's; het ontwikkelen van nieuwe leaseratio's liet hij over aan toekomstig onderzoek' (Elam, 1975, p. 31).

De conclusie van zijn onderzoek was dat indien operationele leases gekapitaliseerd zouden worden, dit de voorspellende waarde van financiële ratios niet verbeterde. Hij vervolgt zijn conclusie met de stelling dat deze uitkomsten niet betekenen dat operationele leases niet gekapitaliseerd moeten worden; informatie over leases kan erg belangrijk zijn voor andere doeleinden welke niet onderzocht zijn in deze studie' (Elam, 1975, p.41).

In een reactie op het artikel van Elam, betoogt Altman, 1976 dat de resultaten van Elam niet echt overtuigend zijn vanwege

1 het achterwege laten van aparte leaseratios's (zoals de contante waarde van de leases/totaal vermogen),

2 het achterwege laten van enkele ratio's waarvan al bewezen was dat deze voorspellende waarde hebben (zoals werkkapitaal/totaal vermogen) en

3 dat de statistische methode enigszins achterhaald was. Vervolgens publiceert Altman (met Haldeman en Narayanan) in 1977 een verbeterde versie van zijn artikel uit 1968 (Altman et al., 1977; Altman, 1968), waarbij de aanpassing voor de operationele leases het 'belangrijkst' (p. 33) is. Het nieuwe model (het zetamodel) berekent een $\mathrm{z}$-score aan de hand van zeven ratio's, waarbij de operationele leases verwerkt worden in de interest-coverage ratio (resultaat voor interest en belastingen gedeeld door interest - inclusief interest in de leases) en in de boekwaarde van vreemd vermogen. Ondanks hun kritiek op Elam (1975) laten Altman et al. (1977) ook het testen van een aparte leaseratio achterwege. Het is dan ook niet bekend in de hoeverre in hun studie de aanpassing voor de operationele leaseverplichtingen heeft geleid tot betere voorspellingen. Dambolena en Khoury (1980) noemen in hun studie expliciet de aanpassing van operationele leases in het zeta-model van Altman et al., maar geven een tweetal argumenten om niet met deze aanpassing mee te gaan in hun eigen studie. Ten eerste vinden zij de resultaten van Elam (1975) overtuigend genoeg om ervan uit te gaan dat het opnemen van de operationele leases aan faillissement voorspelmodellen niet leidt tot betere voorspellingen van deze modellen. Ten tweede betogen zij dat de publiekelijk beschikbare informatie over operationele leases tekortschiet om betrouwbaar de verplichtingen te kapitaliseren.

\section{Lawrence en Bear (1986)}

In 1986 onderzochten ook Lawrence en Bear dezelfde vraag als Elam: verbeteren de voorspellingen van de faillissementvoorspelmodellen door aanpassingen te verrichten voor operationele leases? Ook Lawrence en Bear maakten gebruik van discriminantanalyse, en ook hier werd gebruik gemaakt van het koppelen van ondernemingen; 42 failliete ondernemingen gekoppeld aan 42 niet-failliete ondernemingen. In tegen- 
stelling tot Elam werden ondernemingen die geen melding maakten van operationele leases (in de toelichting) niet uitgesloten van de dataset. Bovendien gebruikten Lawrence en Bear, naast de aanpassing van bestaande financiële ratio's, ook twee nieuwe, specifieke leaseratio's (de 'lease-intensiteit'): de contante waarde van de leaseverplichtingen gedeeld door (1) totaal vermogen en (2) omzet. In navolging van Elam laten de resultaten van Lawrence en Bear een relatief hogere lease-intensiteit zien voor de failliete bedrijven, maar dit verschil is niet statistisch significant. Ook de modellen waarbij ofwel de financiële ratio's zijn aangepast voor de gekapitaliseerde operationele leases, ofwel de lease-intensiteit als variabele is opgenomen, verbeteren niet de nauwkeurigheid van de voorspelmodellen. Lawrence en Bear sluiten zich daarom aan bij de conclusie van Dabolena en Khoury (1980) dat er tot dat moment nog geen bewijs is dat aanpassingen voor operationele leases leiden tot betere voorspellingen van faillissementvoorspelmodellen.

De gemiddelde lease-intensiteit voor zowel de failliete als niet-failliete ondernemingen in de studies van Elam en Lawrence en Bear, zijn grafisch weergegeven in figuur 1. Alhoewel de contante waarde van de operationele leaseverplichtingen ten opzichte van totaal vermogen (PVOL/TV) in beide studies bij failliete ondernemingen hoger ligt dan bij de gezonde ondernemingen, kwamen beide studies tot de conclusie dat het opnemen van de operationele leaseverplichtingen in faillissementvoorspelmodellen niet leidt tot betere voorspellingen van faillissement.
Dit betekent dat de verschillen in de univariate analyse (vergelijking van alleen de relatieve omvang van de operationele leaseverplichtingen) in de modellen onvoldoende hebben geleid tot betere voorspellingen (waarbij de relatie met de andere variabelen ook een rol speelt).

Zowel Elam (1975) als Lawrence en Bear (1986) komen tot de conclusie dat het opnemen van operationele leaseverplichtingen als verklarende variabele in hun faillissementvoorspelmodel niet leidt tot betere voorspellingen, met andere woorden: de nauwkeurigheid van de modellen wordt niet significant verbeterd. In de inleiding is reeds beschreven waarom hernieuwd onderzoek op zijn plaats is. In de volgende paragraaf wordt de methode en dataset van dit artikel beschreven, waarna in paragraaf 4 de resultaten worden gepresenteerd.

\section{Methode en dataset}

Op basis van bepaalde karakteristieken (bijvoorbeeld financiële ratio's) van een onderneming plaatst een faillissementvoorspelmodel ondernemingen in twee categorieën:

1 de ondernemingen waarvan verwacht wordt dat ze failliet gaan, versus

2 de ondernemingen waarvan verwacht wordt dat ze gezond blijven.

De nauwkeurigheid van de classificatie wordt bepaald aan de hand van correct geclassificeerde ondernemingen ${ }^{4}$.

\section{Elam (1975)}

$\mathrm{n}=48$

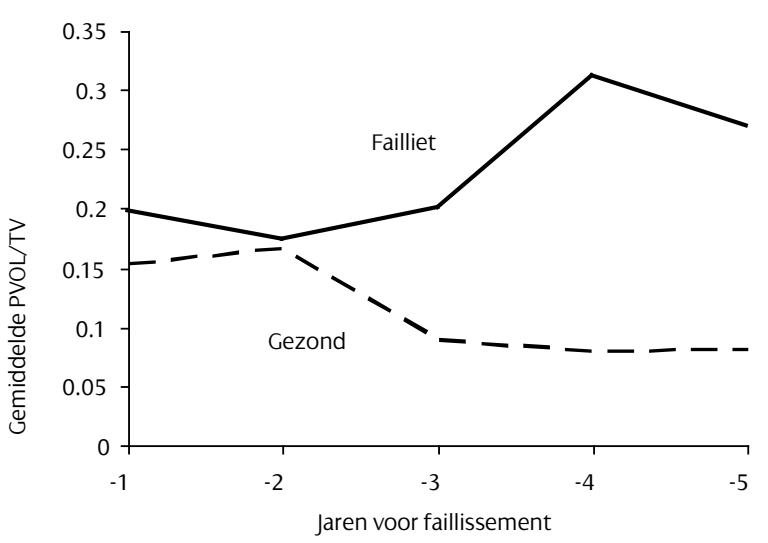

Lawrence and Bear (1986)

$\mathrm{n}=42$

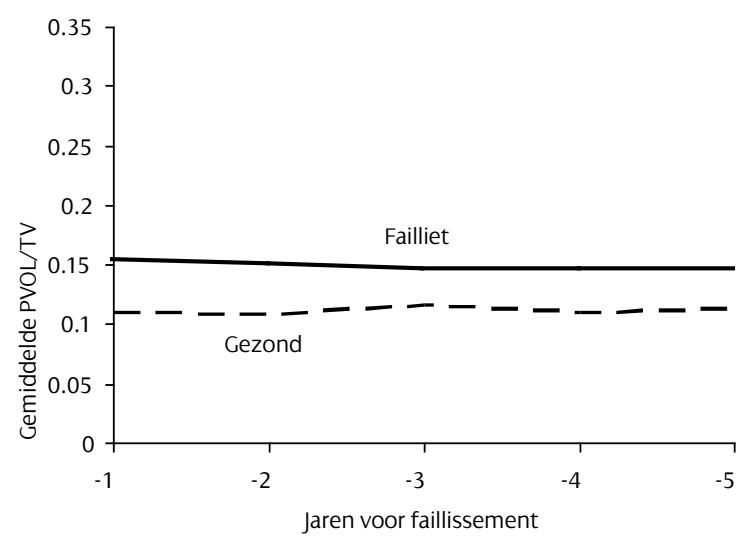


De nauwkeurigheid van het alternatieve faillissementvoorspelmodel (in dit artikel het model met inachtneming van de operationele leaseverplichtingen) wordt getest door het te vergelijken met een basismodel (het model zonder aanpassing voor operationele leaseverplichtingen). Het testen van de hypothese dat een alternatief model (model 2) de nauwkeurigheid van het basismodel (model 1) verbetert, gebeurt aan de hand van de z-waarde, welke als volgt berekend wordt (zie ook Heij et al., 2004; Laitinen en Kankaanpaa, 1999; Elam, 1975; Lawrence en Bear, 1986).

$\mathrm{z}=\frac{\mathrm{CC}_{2}-\mathrm{CC}_{1}}{\sqrt{\mathrm{p}^{\star}(1-\mathrm{p})^{\star} \mathrm{N}}}$

Waar $\mathrm{CC}_{2}-\mathrm{CC}_{1}$ het verschil in correcte classificaties is tussen model 2 en model 1, p de a-selecte kans op correcte classificatie is en $\mathrm{N}$ de totale dataset failliete en gezonde-ondernemingen. $\mathrm{p}$ wordt als volgt berekend:

$\mathrm{p}=\frac{\mathrm{n}_{\mathrm{f}}^{2}}{\mathrm{~N}}+\left(1-\frac{\mathrm{n}_{\mathrm{f}}}{\mathrm{N}}\right)^{2}$

waar $n_{f}$ het aantal failliete ondernemingen in de dataset is.

\section{Methode}

Het onderzoek betreffende het voorspellen van faillissement heeft zich in de afgelopen decennia vooral ontwikkeld op het gebied van de gebruikte statistische methode. In een kort historisch overzicht tonen Laitinen en Kankaanpa (1999) aan dat in 1960 vooral multiple discriminant analyse werd toegepast, wat in de 70 -er en 80 -er jaren vervangen werd door logitanalyse. Daarna volgden alternatieve methoden als 'survival-analysis' ${ }^{5}$ en 'recursive partitioning', en meer recent de toepassing van neurale netweken. Volgens Laitinen en Kankaanpa (1999) werden deze alternatieven echter nooit zo populair als discriminantanalyse en logitanalyse. Bovendien is hun conclusie van een vergelijkend onderzoek tussen de methoden dat de resultaten ten opzichte van discriminant analyse niet verbeteren door de nieuwste voorspeltechnieken. Dit wordt bevestigd door onderzoek van onder andere Pompe en Bilderbeek (2000) en Altman et al. (1994).

Alhoewel de resultaten niet verbeteren verdient logitanalyse toch de voorkeur ten opzichte van discriminantanalyse. Aan de statistische vereisten voor discri- minantanalyse, zoals een normale verdeling voor de verklarende variabelen en gelijke covariantie matrices voor beide groepen ondernemingen, wordt door financiële ratio's vaak niet voldaan (zie ook Barnes, 1987; Lennox, 1999; Pompe en Bilderbeek, 2000). Deze statistische vereisten zijn niet noodzakelijk voor logitanalyse.

Logitanalyse wordt gebuikt om onderscheid te maken tussen twee categorieën, in dit geval tussen failliete en gezonde ondernemingen. Het model schat een logistische regressievergelijking en gebruikt dan een kritische grenswaarde $\mathrm{Z}$ om ondernemingen in de ene of de andere categorie te plaatsen. De afhankelijke variabele is een dummy-variabele, en heeft een waarde van 1 (= failliet) of 0 (= gezond). De logistische vergelijking heeft de volgende vorm:

$$
P(Z)=\frac{1}{1+e^{-\alpha+\beta_{1} X_{1}+\beta_{2} X_{2}+\ldots+\beta_{n} X_{n}+\varepsilon}}
$$

waar $\mathrm{P}(\mathrm{Z})$ de kans is dat de afhankelijke variabele zijn maximum bereikt $(Z=1), e^{x}$ is het natuurlijke logaritme van het grondgetal e $(=2,718), X_{1 . . n}$ zijn de verklarende variabelen en $\beta 1$..n zijn de coëfficiënten, welk de relatie aangeven tussen $\mathrm{X}$ en $\mathrm{Z}$. De logistische regressie is in figuur 2 grafisch weergegeven.

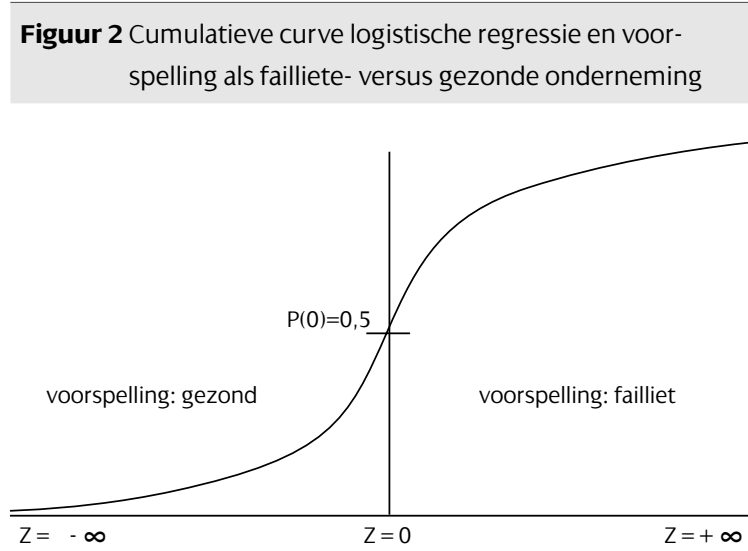

\section{Dataset}

In de studies van Elam (1975) en Lawrence en Bear (1986) werd elke failliete onderneming in de dataset gekoppeld aan een gezonde onderneming ('matched pairs'). Het koppelen vond plaats aan de hand van 1 de sector waarin de failliete onderneming actief is en 2 op basis van de omvang van de ondernemingen. 
Alhoewel meerdere studies elke probleemonderneming koppelen aan een specifiek gekozen gezonde onderneming is hier veel kritiek op (Holmen, 1988; Altman, 1968; Dambolena en Khoury, 1980). Ohlson (1980) stelt bijvoorbeeld dat de variabelen waarmee gekoppeld wordt beter als verklarende variabelen in een model gebruikt kunnen worden dan om mee te koppelen. Het koppelen van ondernemingen is derhalve enigszins arbitrair te noemen. Verschillende studies gebruiken daarom een zo groot mogelijke dataset van gezonde ondernemingen, waardoor het aantal waarnemingen groter is dan bij een gekoppelde datasetstudies (Grice en Dugan, 2001; Beaver et al., 2005; Pompe en Bilderbeek, 2000; Ohlson, 1980). In deze studie zullen beide alternatieven worden uitgevoerd, om zodoende ook een vergelijking met de studies van Elam (1975) en Lawrence en Bear (1986) te kunnen maken.

De ondernemingen in de dataset zijn, of waren, genoteerd op de Euronext Amsterdam, gedurende de periode 1996-2004. In navolging van onder andere Grice en Dugan (2001); Johnsen en Melicher (1994) en Hill et al. (1996) beperkt het onderzoek zich niet tot ondernemingen die daadwerkelijk failliet zijn gegaan, maar zijn ook ondernemingen in de dataset opgenomen die kwetsbaar zijn voor faillissement (financial distress). De volgende criteria zijn gehanteerd om te bepalen of een onderneming in financiële problemen verkeert:

- uitgesproken faillissement;

- uitstel van betaling;

- opheffing of overname ter voorkoming van verder financiële verslechtering;

- schorsing van notering Euronext als gevolg van negatief eigen vermogen;

- negatief eigen vermogen;

- drie jaar achtereenvolgens nettoverlies.

Deze gebeurtenissen zijn opgespoord door middel het archief van Het Financieele Dagblad en de CBSdatabank Statline (overzicht van de reden van het niet meer genoteerd staan aan de Euronext). Uiteindelijk zijn 38 ondernemingen in de dataset opgenomen welke aan één (of meer) van bovenstaande criteria voldeden. Hiervan zijn er 21 daadwerkelijk failliet gegaan of is surseance van betaling aangevraagd. De ondernemingen in financiële problemen, en de daaraan gekoppelde gezonde onderneming (op basis van SIC-code en omvang) zijn weergegeven in appendix 1. De complete set gezonde ondernemingen bestaat uit 62 ondernemingen in de periode 2000-2004 genoteerd op de Euronext, waarbij financiële ondernemingen en ondernemingen die een failliete onderneming zijn opgevolgd, hiervan uitgesloten zijn.

De gegevens met betrekking tot de operationele leaseverplichtingen zijn handmatig verzameld uit de toelichting op de jaarrekening van de ondernemingen. Ondernemingen zonder operationele leaseverplichtingen zijn niet uitgesloten van het onderzoek, zoals wel het geval was bij Elam (1975) maar niet bij Lawrence en Bear (1986). Het uitsluiten van deze ondernemingen is een arbitraire keuze en zou de uitkomst van het onderzoek beïnvloeden. Het kapitaliseren van de operationele leaseverplichtingen gebeurt bij voorkeur aan de hand van een contante waardeberekening (zie ook onder andere Imhoff et al., 1991; Beattie et al., 1998; en LückerathRovers, 2007). Hiervoor zijn de toekomstige operationele leaseverplichtingen met aflossingschema nodig (zoals voorgeschreven door RJ292 of IAS17). Aangezien dertien van de 38 probleemondernemingen hieraan niet voldoen, zijn ook andere schattingsmethoden toegepast om de contante waarde te schatten.

De contante waarde van de operationele leaseverplichtingen (PVOL) is als volgt bepaald voor de set ondernemingen in financiële problemen:

- acht ondernemingen vermeldden geen operationele leases in de toelichting $(\mathrm{PVOL}=0)$;

- veertien ondernemingen rapporteerden minimaal conform RJ292 waardoor PVOL berekend kon worden;

- drie ondernemingen rapporteerden zelf de contante waarde van de operationele leaseverplichtingen;

- vijf ondernemingen rapporteerden de totale operationele leaseverplichtingen zonder aflossingsindicatie, de nominale verplichtingen werden vermenigvuldigd met 0,8 . Deze 0,8 komt voort uit voorgaand empirisch onderzoek waaruit is gebleken dat de contante waarde van de operationele leaseverplichtingen gemiddeld 80 procent bedraagt van de nominale verplichtingen (302 waarnemingen gedurende de periode 2000-2004, zie Lückerath-Rovers, 2007);

- zes ondernemingen rapporteerden de jaarlijkse leaseverplichting. Door middel van een annuiteitenberekening is de contante waarde bepaald, onder de veronderstelling dat de gewogen gemiddelde resterende looptijd vijf jaar bedraagt en de rente 6 procent. (Ook dit is gebaseerd op de gewogen gemiddelde resterende levensduur uit voorgaand onderzoek, Lückerath-Rovers, 2007);

- twee ondernemingen rapporteerden de jaarlijkse leaseverplichting met een indicatie van de resterende looptijd. Voor deze ondernemingen is ook de annuïteitenmethode toegepast, maar met gebruik van de weergegeven resterende looptijd. 


\begin{tabular}{|c|c|c|}
\hline & Model exclusief operationele leases & Model aangepast voor operationele leases \\
\hline \multicolumn{3}{|l|}{ Operationele lease-ratio's } \\
\hline \multirow[t]{2}{*}{ PVOLTV } & & Gekapitaliseerde operationele leases (PVOL) \\
\hline & & Totaal Vermogen \\
\hline \multirow[t]{2}{*}{ PVOL/Omzet } & & Gekapitaliseerde operationele leases (PVOL) \\
\hline & & Omzet \\
\hline \multicolumn{3}{|l|}{ Liquiditeit-ratio's } \\
\hline \multirow[t]{2}{*}{ Current Ratio } & Vlottende activa & Vlottende activa \\
\hline & Vlottende passiva & Vlottende passiva + jaarlijkse leaseverplichting \\
\hline \multirow[t]{2}{*}{ Werkkapitaal/TV } & Vlottende activa - Vlottende passiva & Vlottende activa - Vlottende passasiva - jaarlijkse leaseverplichting \\
\hline & Totaal Vermogen & Totaal Vermogen + PVA \\
\hline \multicolumn{3}{|l|}{ Rentabiliteit-ratio's } \\
\hline \multirow[t]{2}{*}{ EBIT/TV } & Opbrengst voor rente en belasting (EBIT) & $\mathrm{EBIT}+6 \%{ }^{*} \mathrm{PVOL}$ \\
\hline & $\begin{array}{c}\text { Totaal Vermogen } \\
\end{array}$ & Totaal Vermogen + PVA \\
\hline \multirow[t]{2}{*}{ Nettowinst/ Omzet } & Nettowinst & Nettowinst \\
\hline & Omzet & Omzet \\
\hline \multicolumn{3}{|l|}{ Solvabiliteit-ratio's } \\
\hline \multirow[t]{2}{*}{$\mathrm{TVV} / \mathrm{TV}$} & Totaal vreemd vermogen & Totaal vreemd vermogen + PVOL \\
\hline & Totaal Vermogen & Totaal Vermogen + PVA \\
\hline \multirow{2}{*}{$\begin{array}{l}\text { Marktwaarde EV/totaal vreemd } \\
\text { vermogen (ME/TVV) }\end{array}$} & Eindejaars marktkapitalisatie & Eindejaars marktkapitalisatie \\
\hline & $\begin{array}{l}\text { Totaal vreemd vermogen } \\
\end{array}$ & Totaal vreemd vermogen + PVOL \\
\hline \multicolumn{3}{|l|}{ Omzet-ratio } \\
\hline \multirow{2}{*}{ Omzet/TV } & Omzet & Omzet \\
\hline & Totaal Vermogen & Totaal Vermogen + PVA \\
\hline \multicolumn{3}{|l|}{ Cashflow-ratio's } \\
\hline \multirow[t]{2}{*}{ CF/TVV } & Kasstroom & Kasstroom \\
\hline & Totaal vreemd vermogen & Totaal vreemd vermogen + PVOL \\
\hline \multirow[t]{2}{*}{ CF/Omzet } & Kasstroom & Kasstroom \\
\hline & $\overline{\text { Omzet }}$ & $\overline{\text { Omzet }}$ \\
\hline
\end{tabular}

In deze tabel zijn twee operationele lease-ratio's weergegeven die de relatieve omvang van de operationele leaseverplichtingen bepalen (de lease-intensiteit). Deze lease-ratio's zijn berekend door de contante waarde van de operationele leaseverplichtingen (PVOL) te delen door het totaal vermogen (TV) en de Omzet. Daarnaast is het effect weergegeven op negen financiële ratio's als de contante waarde van operationele leaseverplichtingen (PVOL) en de daarbij behorende geleasde activa (PVA) op de balans gekapitaliseerd zouden zijn. Dit heeft gevolgen voor het vreemd vermogen, de totale activa, en resultaat voor interest en belastingen (EBIT). Het effect op EBIT komt voort uit het feit dat de leasetermijnen in zijn geheel aftrekbaar zijn (rente- en aflossingsdeel) terwijl als de leases op de balans gekapitaliseerd zijn de leasetermijn gesplitst wordt in rente en aflossing, en slechts het rentedeel aftrekbaar is. Voor het aflossingsdeel komt vervolgens wel de afschrijving van het actief in de plaats. In dit artikel wordt het effect op de nettowinst niet meegenomen, aangezien uit eerder onderzoek (Lückerath-Rovers, 2007) blijkt dat dit effect minimaal is (slechts als aflossingsdeel en afschrijvingsdeel elkaar erg ontlopen resulteert dit in een groter effect op de nettowinst).

\section{Resultaten}

Tabel 2 toont de gemiddelden van de onderzochte ratio's voor de drie sets ondernemingen; (A) de ondernemingen in financiële problemen $(n=38)$, (B) de daarmee gekoppelde set gezonde ondernemingen $(n=38)$ en $(C)$ de totale set gezonde ondernemingen $(n=62)$. De eerste drie rijen van tabel 3 zijn de drie leaseintensiteit maatstaven, PVOL gerelateerd aan

1 het balanstotaal (zonder dit voor de leases aan te passen, PVOL/TV),
2 het aangepaste balanstotaal (PVOL/TV-na), en 3 de omzet (PVOL/omzet).

De verschillen tussen de ondernemingen in financiële problemen (kolom A) en de totale set gezonde ondernemingen (kolom C) zijn voor alledrie de maatstaven significant positief. PVOL/TV voor de ondernemingen in financiële problemen is bijvoorbeeld 17,4 procent, terwijl het gemiddelde voor de totale set gezondeondernemingen slechts6,7 procent is. De ondernemingen in financiële problemen hebben significant 


\begin{tabular}{|c|c|c|c|c|c|c|c|c|}
\hline & \multicolumn{2}{|c|}{$\begin{array}{c}\text { A } \\
\text { Financiële problemen }\end{array}$} & \multicolumn{3}{|c|}{$\begin{array}{c}\text { B } \\
\text { Gezond -gekoppelde set }\end{array}$} & \multicolumn{3}{|c|}{$\begin{array}{c}\text { C } \\
\text { Gezond - totale set }\end{array}$} \\
\hline & $\mathbf{n}$ & Gemiddelde & $\mathbf{n}$ & Gemiddelde & t-waarde & $\mathbf{n}$ & Gemiddelde & t-waarde \\
\hline \multicolumn{9}{|c|}{ LEASE-INTENSITEIT } \\
\hline 1.PVOL/TV & 36 & 0.174 & 36 & 0.136 & 0.94 & 61 & 0.067 & $3.84^{* * *}$ \\
\hline 2. PVOL/TV-na & 36 & 0.136 & 36 & 0.108 & 1.02 & 62 & 0.068 & $3.04^{* * *}$ \\
\hline 3. PVOL/omzet & 36 & 0.181 & 36 & 0.096 & 1.645 & 61 & 0.059 & $3.25^{* * *}$ \\
\hline \multicolumn{9}{|c|}{ FINANCIELE RATIO'S, VOOR EN NA LEASE-KAPITALISATIE } \\
\hline CR & 35 & 1.428 & 35 & 2.15 & -1.642 & 61 & 1.704 & -0.81 \\
\hline CR-na & 21 & 1.439 & 21 & 2.35 & -1.33 & 60 & 1.598 & -0.42 \\
\hline WK/TV & 35 & 0.109 & 35 & 0.215 & -1.92 & 61 & 0.149 & -0.92 \\
\hline WK/TV-na & 35 & 0.105 & 35 & 0.191 & -1.61 & 61 & 0.140 & -0.84 \\
\hline Omzet/TV & 37 & 1.343 & 37 & 1.653 & $-2.38^{* *}$ & 62 & 1.527 & -1.00 \\
\hline Omzet/TV-na & 36 & 1.142 & 36 & 1.474 & $-3.18^{* * *}$ & 62 & 1.419 & -1.71 \\
\hline Rentedekking & 36 & -12.885 & 33 & 17.149 & $-3.37^{* * *}$ & 54 & 9.589 & $-3.77^{* * *}$ \\
\hline Rentedekking-na & 35 & -8.895 & 32 & 6.788 & $-3.42^{* * *}$ & 55 & 9.974 & $-2.96^{* * *}$ \\
\hline TVV/TV & 37 & 0.709 & 37 & 0.575 & $2.82^{* * *}$ & 62 & 0.587 & $2.84^{* * *}$ \\
\hline TVV/TV-na & 36 & 0.761 & 36 & 0.628 & $2.92^{* * *}$ & 62 & 0.620 & $3.19^{* * *}$ \\
\hline EBIT/TV & 36 & -0.222 & 34 & 0.089 & $-3.58^{* * *}$ & 58 & 0.065 & $-4.07^{* * *}$ \\
\hline EBIT/TV-na & 35 & -0.197 & 33 & 0.082 & $-3.34^{* * *}$ & 58 & 0.065 & $-4.04^{* * *}$ \\
\hline NW/Omzet & 37 & -0.441 & 37 & -0.494 & 0.10 & 61 & -0.292 & -0.36 \\
\hline CF/TVV & 37 & -0.318 & 37 & -0.141 & -0.43 & 62 & 0.000 & -1.01 \\
\hline CF/TVV-na & 36 & -0.294 & 36 & -0.105 & -0.57 & 62 & 0.022 & -1.26 \\
\hline CF/Omzet & 37 & -0.325 & 37 & -0.325 & 0.18 & 61 & -0.223 & -0.26 \\
\hline ME/TVV & 37 & 1.739 & 36 & 4.408 & $-2.58^{* *}$ & 61 & 3.485 & -1.38 \\
\hline ME/TVV-na & 36 & 1.402 & 35 & 2.974 & $-2.17^{* *}$ & 61 & 2.826 & -1.42 \\
\hline LnOmzet & 37 & 11.680 & \multicolumn{3}{|c|}{ Gebruikt om te matchen } & 61 & 13.380 & $-3.64^{* * *}$ \\
\hline
\end{tabular}

meer operationele leases. De gekoppelde gezonde ondernemingen (kolom B) hebben ook minder operationele leases dan de ondernemingen in financiële problemen, maar deze verschillen zijn voor geen van de drie maatstaven significant ${ }^{7}$. Dit kan betekenen dat de variabelen waarmee gekoppeld is (bedrijfstak en omvang), ook mede bepalen of een onderneming veel of weinig least, waardoor de hoge lease-intensiteit bij de ondernemingen in financiële problemen mede door deze karakteristieken wordt bepaald. Figuur 3 illustreert de verschillen in lease-intensiteit tussen de drie sets ondernemingen. Figuur 3 is vergelijkbaar met figuur 1 waarin het verloop van de verschillen tot vier jaar voor faillissement $(t=-1$ tot $t=-4)$ tussen failliete en gezonde ondernemingen in de studies van Elam (1975) en Lawrence en Bear (1986) werd getoond, met dien verstande dat figuur 3 alleen het laatste jaar voor faillissement laat zien $(t=-1)$ in plaats van vier jaar en in figuur 3 additioneel ook het verschil met de totale set gezonde ondernemingen wordt weergegeven.
Voor de overige financiële ratio's uit tabel 3 zijn de verschillen significant tussen de set ondernemingen in financiële problemen en de twee sets gezonde ondernemingen wat betreft de rentedekking (negatieve relatie), de solvabiliteitsratio totaal vreemd vermogen ten opzichte van totaal vermogen (positieve relatie) en de ratio operationele winst ten opzichte van totaal vermogen (negatieve relatie). Omzet gedeeld door totaal vermogen is alleen in de gekoppelde set significant en de overige ratio's zijn niet significant in de univariate analyse. Opvallend is dat het voor de significante variabelen niet uitmaakt of de ratio's met of zonder aanpassing voor de contante waarde van de operationele leases worden berekend. Dit is een indicatie dat het in de voorspelmodellen ook niet uitmaakt of de ratio's met of zonder aanpassing voor operationele leases worden gebruikt en dat het opnemen van de operationele leases in de voorspelmodellen in dat geval geen toegevoegde waarde heeft. 


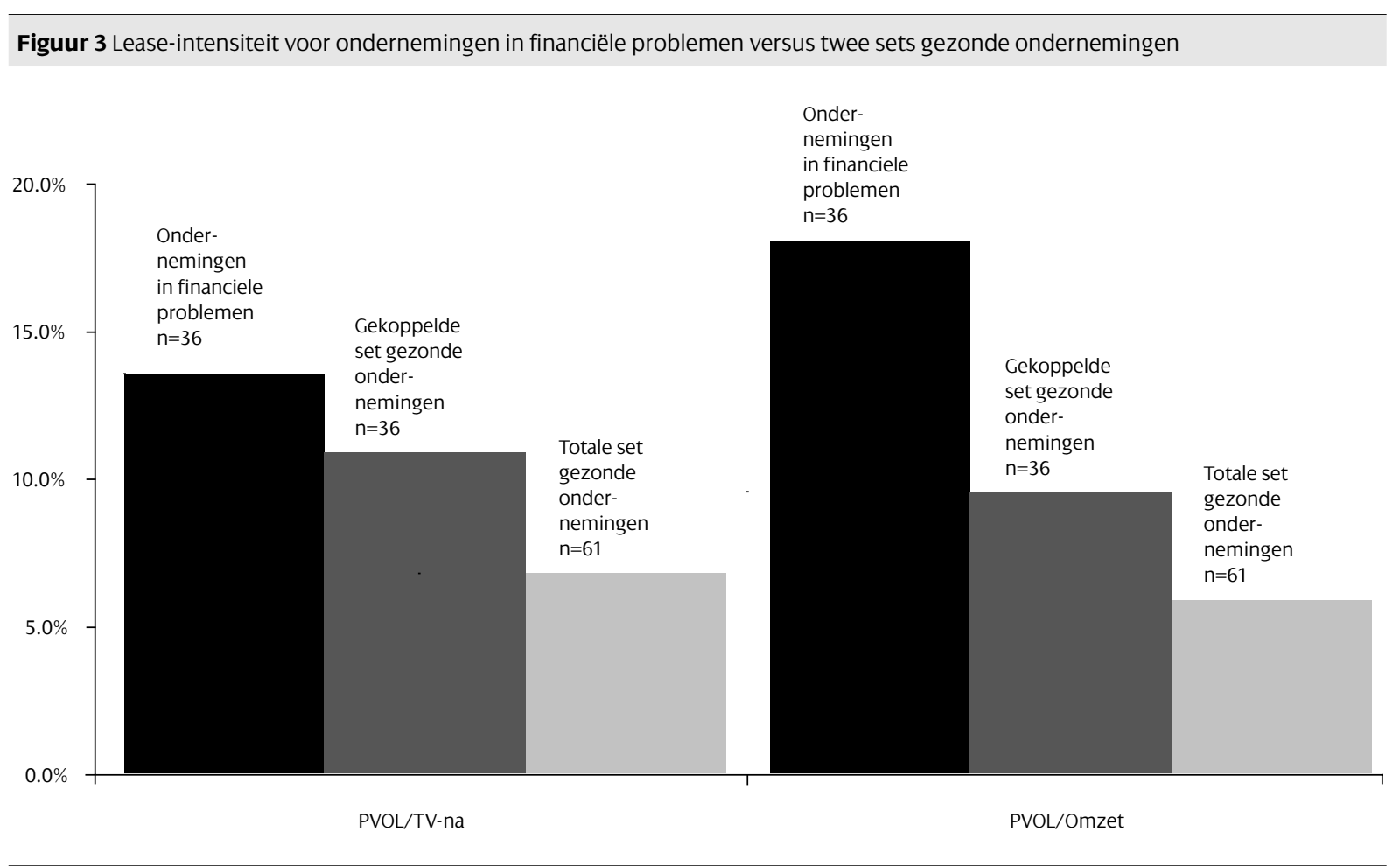

Vervolgens zijn de financiële ratio's getest in de logitmodellen. Er zijn vier verschillende modellen geconstrueerd en deze modellen verschillen als volgt van elkaar: model I is het basismodel waarin alle financiële ratio's zijn opgenomen zonder rekening te houden met de operationele leaseverplichtingen. Model II is als model I, maar nu met een aanpassing in financiële ratio's voor operationele leaseverplichtingen (zie tabel 2). In model II zijn dus nog niet de lease-intensiteit maatstaven zelf opgenomen. Model III is gelijk aan model II maar nu met ook de leaseintensiteit maatstaf PVOL/TV-na als aparte variabele. Model IV is weer gelijk aan het basismodel I (dus zonder aanpassing aan de financiële ratio's) maar met de lease-intensiteit (PVOL/TV-na) als aparte variabele. Elk van de vier modellen is getest voor zowel de gekoppelde set als voor de totale set gezonde ondernemingen, hierdoor zijn er in totaal acht modellen.

Voordat de toegevoegde waarde van operationele leases in deze modellen wordt beschreven, worden nu eerst de (statistische) verschillen tussen

1 een gekoppelde set gezonde ondernemingen en een totale set gezonde ondernemingen en

2 tussen discriminant analyse en logitanalyse beschreven. Uit tabel 4 komt naar voren dat de nauwkeurigheid (percentage correct geclassificeerd) voor alle vier de modellen I tot IV hoger is bij het gebruik van de totale set gezonde ondernemingen (varieert van $89,7 \%$ tot $93,0 \%$ ), dan bij het gebruik van de gekoppelde set gezonde ondernemingen (varieert van $82,4 \%$ tot $83,8 \%$ ). Het verschil voor wat betreft model I is 83,8 procent voor de gekoppelde set en 89,7 procent voor de totale set gezonde ondernemingen. Dit verschil is significant op $1 \%$-niveau ( $\mathrm{z}$-waarde $=6,3$ ). Het verdient derhalve de voorkeur de conclusies te baseren op de totale set gezonde ondernemingen. Dit is in tegenstelling tot de methodiek van Elam (1975) en Lawrence en Bear (1986) waarbij de gekoppelde set gezonde ondernemingen werd gebruikt, maar in lijn met bijvoorbeeld Beaver et al., (2005); en Pompe en Bilderbeek, (2000).

Aangezien deze studie niet alleen van Elam (1975) en Lawrence en Bear (1986) afwijkt in de samenstelling van de set gezonde ondernemingen maar ook in de gebruikte statistische methode, zijn ook de verschillen in nauwkeurigheid tussen logitanalyse en discriminantanalyse getest. Uitgaande van de totale set gezonde ondernemingen bedraagt het percentage "correct voorspeld" met discriminantanalyse van model I 86,2 procent (niet opgenomen in tabel 4) en met logitanalyse is dit 89,7 procent. Dit verschil is echter niet significant $(z=0,64)$ en komt derhalve overeen met de voorgaande studies, van onder anderen Laitinen en Kankaanpaa, (1999) en Pompe en Bilderbeek, (2000), waarin wordt geconcludeerd 


\begin{tabular}{|c|c|c|c|c|c|c|c|c|}
\hline & \multicolumn{4}{|c|}{ GEKOPPELDE SET GEZONDE ONDERNEMINGEN } & \multicolumn{4}{|c|}{ TOTALE SET GEZONDE ONDERNEMINGEN } \\
\hline & Model I & Model II & Model III & Model IV & Model I & Model II & Model III & Model IV \\
\hline Constante & -0.57 & -2.69 & -2.32 & -0.59 & 6.70 & 7.74 & 7.28 & 9.94 \\
\hline PVOLTV-na & & & 1.78 & $6.88^{*}$ & & & -1.23 & $10.27^{* *}$ \\
\hline CR & 0.04 & -0.18 & -0.26 & -0.1 & $4.77^{* *}$ & 1.01 & 1.29 & 2.93 \\
\hline WK/TV & 0.71 & 3.89 & 4.21 & 1.98 & $-13.37^{* *}$ & -2.44 & -3.20 & -8.45 \\
\hline Omzet/TV & -0.44 & -0.69 & -0.68 & -0.73 & -1.41 & -1.26 & -1.26 & $-1.62^{*}$ \\
\hline Rentedekking & 0.01 & 0.02 & 0.02 & 0.01 & -0.23 & $-0.42^{* *}$ & $-0.45^{*}$ & -0.15 \\
\hline TVV/TV & 2.93 & $5.37^{*}$ & 4.68 & 2.7 & 5.34 & 4.94 & 5.59 & 3.26 \\
\hline $\mathrm{EBIT} / \mathrm{TV}$ & 3.14 & -3.4 & -3.4 & 3.34 & $27.32^{* * *}$ & $36.68^{* * *}$ & $38.12^{* * *}$ & $29.04^{* * *}$ \\
\hline NW/Omzet & 2.78 & -1.51 & -2.01 & 2.85 & $34.92^{*}$ & 16.94 & 17.12 & 29.77 \\
\hline CF/TVV & -8.88 & -8.34 & -8.35 & -9.99 & -14.61 & $-36.11^{* *}$ & $-36.73^{* *}$ & $-30.02^{* *}$ \\
\hline CF/Omzet & -4.01 & 5.68 & 6.11 & -3.78 & $-57.43^{*}$ & -21.84 & -21.91 & -41.45 \\
\hline ME/TVV & -0.11 & -0.14 & -0.17 & -0.21 & -0.14 & -0.05 & -0.04 & -0.1 \\
\hline LnOmzet & \multirow{2}{*}{\multicolumn{4}{|c|}{ Gebruikt om te matchen }} & $-0.99^{* * *}$ & $-0.81^{* * *}$ & $-0.83^{* * *}$ & $-0.97^{* * *}$ \\
\hline Industrie dummie & & & & & $0.90^{* *}$ & 0.58 & 0.62 & 0.73 \\
\hline Nagelkerke R2 & 0.51 & 0.52 & 0.52 & 0.57 & 0.59 & 0.67 & 0.78 & 0.8 \\
\hline Correct geclassificeerd & $83.8 \%$ & $83.8 \%$ & $82.4 \%$ & $82.4 \%$ & $89.7 \%$ & $92.0 \%$ & $92.0 \%$ & $93.0 \%$ \\
\hline z t.o.v. random model1 & 5.58 & 5.58 & 5.34 & 5.34 & 7.05 & 7.39 & 7.39 & 7.58 \\
\hline z t.o.v. model 12 & & 0.00 & -0.24 & -0.24 & & 0.43 & 0.43 & 0.43 \\
\hline
\end{tabular}

1 De z-waarde is voor alle modellen (inclusief model I) ten opzichte van een random model (voorspellingen zonder gebruik te maken van verklarende variabelen maar random

ingedeeld in failliet versus gezond) significant met $99 \%$ betrouwbaarheid.

2 De $z$-waarde voor de modellen II-IV ten opzichte van model I is niet significant $(90 \%$ betrouwbaarheidsinterval).

dat door logitanalyse de resultaten van discriminantanalyse niet significant verbeteren.

Voorgaande analyse heeft zich vooral gericht op de samenstelling van de dataset en het gebruik van de statistische methode. In het navolgende wordt nu de toegevoegde waarde van het opnemen van de operationele leases in de modellen II tot IV ten opzichte van het basismodel I beschreven, waarbij de resultaten van de totale set gezonde ondernemingen worden gebruikt. In het basismodel I, zonder op enige wijze rekening te houden met operationele leases, wordt 89,7 procent correct geclassificeerd. Dit is significant beter dan de classificatie op basis van een random-model ( $\mathrm{z}$-waarde $=7,05)$. Van deze vier modellen heeft tenslotte model IV, (financiële ratio's niet aangepast maar wel een aparte lease-intensiteit maatstaf), het beste resultaat: 93,0 procent van de ondernemingen is correct geclassificeerd. Ten opzichte van het basismodel is dit een stijging van 3,3 procent, maar dit is statistisch geen significante verbetering. De lease-intensiteit maatstaf (PVOL/TV) heeft in dit model wel een positieve, statistisch significante, relatie met de classificatie als onderneming in financiële problemen.
Tenslotte dient te worden opgemerkt dat de dummy voor de industrie een significante voorspellende variabele is in model I (bij de vergelijking met de totale set gezonde ondernemingen) maar dit niet meer het geval is als de operationele leases als verklarende variabele in het model worden opgenomen. De verhoogde lease-intensiteit bij de ondernemingen in financiële problemen wordt blijkbaar mede bepaald door de bedrijfstak waarin de ondernemingen zich bevinden. Een nadere analyse van de bedrijfstak laat zien dat de relatie tussen de sector ICT en de kans op faillissement significant is (Pearson chi-square 9,2, significant op 1\%-niveau). Deze sector heeft bovendien een significant hogere lease-intensiteit (PVOL/ $\mathrm{TV}=15,8 \%$ ten opzichte van $7,9 \%, \mathrm{t}=2,66$ ) Dit bevestigt het argument van Ohlson (1980) dat het koppelen van failliete en gezonde ondernemingen op basis van de bedrijfstak de resultaten beïnvloedt.

De resultaten van de modellen zijn consistent met de resultaten van de univariate analyses. Ondernemingen in financiële problemen hebben gemiddeld meer operationele leaseverplichtingen dan gezonde ondernemingen, maar zowel in univariate verschillenanalyse als in de voorspelmodellen leidt dit niet tot een 
significante verbetering van de nauwkeurigheid van de classificatie in gezonde dan wel in financiële problemen verkerende ondernemingen. Dit is in overeenstemming met de resultaten van Elam (1975) en Lawrence en Bear (1986) waarbij de univariate analyse (figuur 1) een duidelijk verschil tussen failliete en gezonde ondernemingen liet zien, maar dit verschil leidde niet tot betere voorspellingen van faillissement in het faillissementvoorspelmodel. Nader onderzoek naar de oorzaak van de verhoogde operationele lease-intensiteit bij ondernemingen in financiële problemen zou dit wellicht kunnen verklaren. Vragen die namelijk nu niet zijn beantwoord zijn, bijvoorbeeld: hebben de ondernemingen meer operationele leases omdat ze in financiële problemen geraken, of geraken ze in financiële problemen doordat ze meer operationele lease hebben? En, hebben de ondernemingen in financiële problemen zelf gekozen voor meer operationele leases of zijn ze hiertoe min of meer gedwongen doordat financiers geen ander vorm van financiering beschikbaar stelden?

\section{Conclusie}

In dit artikel is onderzocht of informatie over operationele leaseverplichtingen, die door ondernemingen wordt verstrekt in de toelichting op de balans en de winst- en verliesrekening, kan leiden tot betere voorspellingen van faillissementvoorspelmodellen indien deze informatie hierin wordt opgenomen. Elam (1975) en Lawrence en Bear (1986) toonden in eerdere studies aan dat dit niet het geval was. De gedateerde statistische methode (discriminant analyse), de toegenomen informatie over operationele leases en de groei van operationele leases sinds deze studies rechtvaardigden een hernieuwd onderzoek. De onderzoeksvraag is actueel en relevant aangezien de regelgevers IASB en FASB momenteel gezamenlijk onderzoeken of alle leases op de balans verwerkt dienen te worden om zodoende de gebruiker van de jaarrekening beter in staat te stellen de informatie in de financiële analyse van ondernemingen mee te nemen. Indien de gekapitaliseerde operationele leaseverplichtingen leiden tot betere voorspellingen van faillissementvoorspelmodellen zou dit een argument kunnen zijn om inderdaad de kapitalisatie van alle leases te verkiezen boven de huidige on- en off-balance benadering van financiële respectievelijk operationele leases.

Op basis van de resultaten gepresenteerd in dit artikel kom ik tot de volgende conclusies met betrekking tot de statistische technieken bij het voorspellen van faillissement. Het aantal correct geclassificeerde onder- nemingen verbetert significant bij gebruik van een totale set gezonde ondernemingen in plaats van het maken van koppels gezonde- en probleemondernemingen. De nauwkeurigheid van het voorspellen, alhoewel statistisch niet significant, is hoger bij logitanalyse ten opzichte van discriminantanalyses. Bovendien voldoen de statistische eigenschappen van financiële ratio's niet aan de eisen van discriminantanalyse. Concluderend kan gesteld worden dat voor het voorspellen van financiële problemen bij ondernemingen bij voorkeur een totale set gezonde ondernemingen gebruikt dient worden en dat daarbij logitanalyse dient te worden toegepast.

Verder hebben probleemondernemingen gemiddeld meer operationele leaseverplichtingen dan gezonde ondernemingen, maar dit verandert de statistische uitkomsten van de vergelijking tussen deze twee groepen ondernemingen niet. Met andere woorden: dezelfde financiële ratio's blijven in dezelfde mate significant verschillen tussen de twee groepen ondernemingen. Bovendien wordt de nauwkeurigheid van de voorspelmodellen niet significant verbeterd door het opnemen van de operationele leaseverplichtingen en komt de verhoogde lease-intensiteit mede voort uit het gegeven dat veel ondernemingen in de set van probleemondernemingen in financiële problemen zich in de ICT-sector bevinden, welke sector een verhoogde lease-intensiteit heeft. Dit verklaart mede waarom de verschillen in lease-intensiteit tussen gekoppelde (op basis van omvang en sector) gezondeen probleemondernemingen niet significant zijn.

Eerder onderzoek heeft aangetoond dat de financiële analyse van een onderneming, en het vergelijken van ondernemingen onderling, op basis van financiële ratio's onbetrouwbaar en onvolledig is als de operationele leases daarin niet worden meegenomen (Lückerath-Rovers, 2004; Lückerath-Rovers, 2007). Dit geldt ook voor ondernemingen in financiële problemen. In deze studie is echter niet aangetoond dat het voorspellen van mogelijk faillissement significant verbetert door in de modellen operationele leases als verklarende variabele mee te nemen. Derhalve is de conclusie gelijk aan de conclusie van Elam (1975, p. 41): voor het voorspellen van faillissement is het kapitaliseren van operationele leases niet noodzakelijk. Dit betekent uiteraard niet dat er geen andere argumenten zijn waarom dat wel gewenst is. 


\section{Appendix}

Tabel 4 Ondernemingen in financiële problemen en de matched set gezonde ondernemingen

\begin{tabular}{|c|c|c|c|c|}
\hline Laatste jaarverslag & Probleem ondernemingen & Criterium & Primaire sic-code & Gezonde ondernemingen \\
\hline 1999 & Baan Company & Failliet & 73 & Simac Techniek \\
\hline 1999 & Atag group & Failliet & 36 & Nederlands Apparatenfabriek \\
\hline 1999 & Alanheri & 3 jaar verlies & 51 & Amsterdam Commodities \\
\hline 1999 & Burgman Heybroek & 3 jaar verlies & 50 & Econosto \\
\hline 1999 & Dico International & 3 jaar verlies & 50 & Oranjewoud \\
\hline 1999 & EVC International & 3 jaar verlies & 28 & Fornix Biosciences \\
\hline 1999 & Begemann Koninklijke Groep & Failliet & 67 & HAL Trust \\
\hline 1999 & Management Share & Uitstel van betaling & 73 & ICT Automatisering \\
\hline 1999 & And International Publishers & Uitstel van betaling & 73 & Brunel International \\
\hline 1999 & RING!ROSA & Failliet & 73 & Hitt \\
\hline 2000 & HES-Beheer & 3 jaar verlies & 42 & Smit International \\
\hline 2000 & De Vries Robbe Groep & Uitstel van betaling & 17 & Batenburg Beheer \\
\hline 2000 & LCI Technology & Failliet & 73 & Unit 4 Agresso \\
\hline 2000 & Pharming Group & Uitstel van betaling & 80 & Crucell \\
\hline 2000 & Toolex International & Failliet & 35 & Draka Holding \\
\hline 2000 & KPNQwest & Failliet, 3 jaar verlies & 73 & PINKROCCADE \\
\hline 2000 & Koninklijke textielgroep Twenthe & Failliet & 23 & Blydenstein-Willink \\
\hline 2000 & Landis & Failliet & 73 & Athlon Holding \\
\hline 2001 & Getronics & 3 jaar verlies, negatief EV & 73 & USG People \\
\hline 2001 & Tie Holdings & 3 jaar verlies & 73 & Blue Fox Enterprises \\
\hline 2001 & Vedior & 3 jaar verlies & 73 & Randstad Holding \\
\hline 2001 & EMIS & Failliet & 87 & Rood Testhouse \\
\hline 2001 & Laurus & Negatief EV & 54 & Schuitema \\
\hline 2001 & UPC & Uitstel van betaling & 29 & TNT \\
\hline 2001 & Punch Technix & Negatief EV & 35 & Tulip Computers \\
\hline 2001 & CSS & Failliet & 48 & Exact Holding \\
\hline 2001 & AINO & Failliet & 73 & Scala Business Solution \\
\hline 2001 & Versatel Telecom International & Uitstel van betaling, negatief EV & 48 & KPN \\
\hline 2002 & Asml Holding & 3 jaar verlies & 35 & ASM International \\
\hline 2002 & BE Semiconductor Industries & 3 jaar verlies & 35 & Airspray \\
\hline 2002 & Qurius & 3 jaar verlies & 50 & Kendrion \\
\hline 2002 & Priority Telecom & 3 jaar verlies & 48 & New Skies Sattelites \\
\hline 2002 & Neways Electric International & 3 jaar verlies & 50 & Eriks Group \\
\hline 2002 & Numico & Negatief EV & 20 & CSM \\
\hline 2002 & Van heek-Tweka & Failliet & 23 & McGregor Fashion Group \\
\hline 2003 & Vilenzo International & Uitstel van betaling & 23 & Ten cate \\
\hline 2003 & Exendis & 3 jaar verlies & 36 & Docdata \\
\hline 2003 & RT Company & Uitstel van betaling & 73 & Ctac \\
\hline
\end{tabular}




\section{Literatuur}

Altman, E.I. (1968), Financial ratios, discriminant analysis and the prediction of corporate bankruptcy, The journal of Finance, vol. 23, no.4, pp. 589-609.

Altman, E.I. (1976), Capitalization of leases and the predictability of financial ratios: a comment, The Accounting Review, vol. 51, no.2, pp. 408-412.

Altman, E.I., R. Haldeman en P. Narayanan (1977), ZETATM analysis: a new model to identify bankruptcy risk of corporations, Journal of Banking and Finance, vol. 1, no. 1, pp. 29-54.

Barnes, P. (1987), The analysis and use of financial ratios: a review article, Journal of Business Finance and Accounting, vol. 14, no. 4 (Winter), pp. 449-461.

Beattie, V., K. Edwards en A. Goodacre (1998), The impact of constructive operating lease capitalisation on key accounting ratios, Accounting and Business Research, vol. 28, no.4, pp. 233-254.

Beaver, W.H., M.F. McNichols en J.W. Rhie (2005), Have financial statements become less informative? Evidence from the ability of financial ratios to predict bankruptcy., Review of Accounting Studies, vol. 10, pp. 93-122.

Bennet, B.K. en M E. Bradbury (2003), Capitalizing non-cancelable operating leases, Journal of International Financial Management and Accounting, vol. 14, no.2, pp.101-114.

Collins, R.A. en R.D. Green (1982), Statistical methods for bankruptcy forecasting, Journal of Economics and Business, vol. 34, no.4, pp. 349-354. Dambolena, I.G. en S. J. Khoury (1980), Ratio stability and corporate failure, Journal of Finance, vol. 35, no.4, pp. 1017-1026.

Dimitras, A.I., S.H. Zanakis en C. Zopounidis (1996), A survey of business failures with an emphasis on prediction methods and industrial applications, European Journal of Operational Research, vol. 90, pp. 487-513.

Elam, R. (1975), The effect of lease data on the predictive ability of financial ratios, The Accounting Review, vol. 50, no.1, pp.25-43.

Ely, K. M. (1995), Operating lease accounting and the market's assessment of equity risk, Journal of Accounting Research, vol. 33, no.2, pp. 397-415.

Financial Accounting Standards Board (1980), Qualitative characteristics of accounting information, Statement of Financial Accounting Concepts No.2; zie: www.fasb.org.

Grice, J.S. en M.T. Dugan (2001), The limitations of bankruptcy prediction models: some cautions for the researcher, Review of Quantitative Finance and Accounting, vol. 17, no. 2, pp.151-166.

Heij, C., P. Boer de, P.H. Franses, T. Kloek en H.K. van Dijk (2004). Econometric methods with applications in business and economics, Oxford Univeristy Press.

Hill, N.T., S.E. Perry en S. Andes (1996), Evaluating firms in financial distress: an event history analysis, Journal of Applied Business Research, vol. 12, no.3, pp. 60-71.

Holmen, J.S. (1988), Using financial ratios to predict bankruptcy: an evaluation of classic models using recent evidence, Akron Business and Economic Review, vol. 19, no. 1 (Spring), pp.52-63.

International Accounting Standards Board (2000), G4+1 Position paper: Leases, implementation of a new approach.

International Accounting Standards Board (2003), Framework for preparation and presentation of financial statements.
International Accounting Sttandards Board (2006). IASB Update, July 2006, www.iasb.org.

Imhoff, E.A., R.C. Lipe en D.W. Wright (1991), Operating leases: impact of constructive capitalization, Accounting Horizons, vol. 5, pp. 51-63.

Imhoff, E.A., R.C. Lipe en D.W. Wright (1997), Operating leases: income effects of constructive capitalization, Accounting Horizons, vol. 11, no.2, pp. 12-32.

Johnsen, T. en R.W. Melicher (1994), Predicting corporate bankruptcy and financial distress: information value added by multinominal logit models, Journal of Economics and Business, vol. 46, pp.269-286.

Laitinen, T. en M. Kankaanpaa (1999), Comparative analysis of failure prediction methods: the Finnish case, The European Accounting Review, vol. 8, no.1, pp. 67-92.

Lawrence, E.C. en R. M. Bear (1986), Corporate bankruptcy prediction and the impact of leases, Journal of Business, Finance and Accounting, vol. 13, no.4, pp. 571-585.

Leaseurope (2005). Leasing activity in Europe, key facts and figures, www. leaseurope.org.

Lennard, A. en H. Nailor (2000). Leases: implementation of a new approach. Lennox, A. (1999), Identifying failing companies: a re-evaluation of the logit, probit and DA approaches, Journal of Economics and Business, vol. 51, pp. 347-364.

Lückerath-Rovers, M. (2004), Operating Leases: een niet te onderschatten post, Maandblad voor Accountancy en Bedrijfseconomie, vol.78, no. 11 (november), pp.497-506.

Lückerath-Rovers, M. (2007), Operating-lease disclosure. an empirical investigation, PhD-thesis, Erasmus University; zie: http://hdl.handle. net/1765/9507.

McGregor, W. (1996). Accounting for leases: a new approach. Recognition by lessees of assets and liabilities arising under lease contracts.

Ohlson, J.A. (1980), Financial ratios and the probabilistic prediction of bankruptcy, Journal of Accounting Research, vol. 18, no.1, pp.109-131.

Pompe, P.P.M. en J. Bilderbeek (2000), Prestaties van modellen en ratio's bij het voorspellen van faillissementen, Maandblad voor Accountancy en Bedrijfseconomie, vol. 73, no. 10 (oktober), pp. 465-472.

Securities and Exchange Commission (2005), Report and recommendations pursuant to section 401(c) of the Sarbanes-Oxley Act of 2002 on arrangements with off-balance sheet implications, special purpose entities and transparency of filings by issuers.

\section{Noten}

1 Bij een operationele lease komt alleen de leasebetaling tot uitdrukking in de winst- en verliesrekening; bij financial lease wordt het actief geactiveerd en wordt de leaseverplichting (contante waarde van de toekomstige leasebetalingen) gepassiveerd. In de winst- en verliesrekening worden opgenomen de afschrijvingen en het rentebestanddeel in de leasetermijn. De leaseverplichting wordt op de balans opgenomen tegen amortisatiewaarde.

2 Gevolgd in 1982 door IAS 17 en in 1984 in Nederland door Richtlijn 1.01.1, nu Richtlijn 292.

3 De kwalitatieve criteria zijn: begrijpelijkheid, relevantie, betrouwbaarheid en vergelijkbaarheid (IASB Framework, paragraaf 24).

4 Twee soorten fouten kunnen hierbij gemaakt worden; - een Type-1 
fout: een failliete onderneming was geclassificeerd als gezond, of een Type-2 fout: een gezonde onderneming werd verwacht failliet te gaan. Type-1 fouten worden soms ernstiger gevonden dan Type-2 fouten. Dit kan als volgt verklaard worden. Stel dat een bank geld leent aan een onderneming waarvan voorspeld is dat deze gezond blijft. Als de onderneming toch failliet gaat (Type-1 fout), kunnen de kosten van de misclassificatie oplopen tot de volledige uitgeleende hoofdsom. In geval een onderneming gezond blijft waarbij voorspeld was dat de onderneming failliet ging (Type-2 fout), heeft de bank wellicht de lening niet verstrekt en de kosten van de misclassificatie bedragen dan de gemiste opbrengsten (de rentemarge) op de lening. Om dit te voorkomen kunnen onderzoekers een lagere drempel instellen voor het classificeren als gezond of aan de typen fout een verschillend gewicht toekennen.

5 Survival analysis is een techniek waarbij gekeken wordt naar de tijd voor een bepaalde gebeurtenis (event-studie). Het wordt bijvoorbeeld vaak toegepast bij sociale studies waarbij gekeken wordt wat-, en hoeveel tijd, vooraf gaat aan de onderzochte gebeurtenis, bijvoorbeeld verandering van baan, huwelijk, krijgen van kinderen, overlijden.

6 Recursive partitioning plaatst ondernemingen ook in twee categorieën, failliete versus gezonde ondernemingen, maar zoekt ook naar verborgen patronen of relaties in de financiële ratio's of naar significante sub-groepen in de dataset van ondernemingen om zo de relatie tussen de financiële ratio's en de kans op faillissement beter te begrijpen.

7 De resultaten zijn hetzelfde bij de analyse van de (non-parametrische) mediaan-test. 